\title{
Estratégias para aprendizagem interativa
}

\author{
Geraldina Porto Witter ${ }^{1}$
}

Buehl, D. 2001. Classroom strategies for interative learning. Newark: IRA, v + 170 p.

A preocupação com um processo ensinoaprendizagem com ampla participação dos alunos não é recente. Todavia, diante dos avanços da tecnologia de ensino e da competitividade dos meios de informação, muitas vezes desviando a atenção, exagerando no volume de informações ou descuidando da qualidade das mesmas, se tornou mais relevante a preocupação com a interatividade na aprendizagem, especialmente quando há textos envolvidos.

O livro de Doug Bueh se encaixa entre os que estão sendo produzidos enfocando essa problemática. O autor é especialista na área e traz uma contribuição muito útil a quem quer que se ocupe com as questões de ensino-aprendizagem em qualquer nível.

O Prefácio foi escrito por Carol M. Santa, diretora da Education Montana Academy que enaltece as qualidades do docente e pesquisador, bem como, destaca a necessidade e praticidade do livro.

A Introdução do livro é muito breve e nela o leitor é informado da motivação do autor ao escrevê-lo difundir tecnologia de eficiência comprovada para que os alunos possam aprender melhor, para ajudar os docentes a alcançar essa meta.

O livro é composto por duas partes, sendo a primeira de cunho mais teórico, compreendendo três capítulos que tratam do desenvolvimento de aprendizes e leitores capazes de usar estratégias que levem ao desenvolvimento pessoal. A segunda parte é maior sendo constituída pela apresentação de 46 procedimentos estratégicos para o ensino e a aprendizagem. Além disso, a obra apresenta um Apêndice muito útil do prisma didático, mas que também é útil para se trabalhar a prevenção e fazer intervenção com pessoas com problemas de aprendizado especialmente na área verbal. O leitor encontra aí 17 instrumentos.

A bibliografia citada é de qualidade, recente, predominantemente constituída por artigos de periódicos científicos, o que é uma recomendação adicional à leitura do livro.

O primeiro capítulo é uma apresentação da perspectiva interativa na aprendizagem com ênfase na leitura, mais especificamente na compreensão da leitura.

\footnotetext{
1 Endereço para correspondência:
}

Av: Pedroso de Moraes, 144 Cx. P.302 -

Pinheiros, São Paulo- SP, 05420-000.
O enfoque dado é predominantemente construtivista em termos da linguagem do autor mas são perfeitamente assimiláveis por outros enfoques além de apontarem para a transteoria, pode-se mesmo dizer que são universais. A compreensão da leitura compreende: o contexto (ambiente, tarefa, resultado, contingências), o texto (conteúdo, formato, inteligibilidade, conceitos, organização e objetivos do autor) e o leitor (experiências pessoais, conhecimento da matéria, objetivos, motivação e vocabulário). Em face desses elementos é que devem ser escolhidas as estratégias de compreensão, as quais podem ser classificadas pelo tipo de atividades a serem desempenhadas pelos alunos e pelos processos cognitivos requeridos do estudante.

O capítulo seguinte trata do pensar usando as estruturas de referência textuais que podem corresponder a diversas estratégias de ensino. É um capítulo muito breve e no qual o autor apresenta um questionário-roteiro para ajudar o leitor a identificar as estruturas essenciais do texto e um outro roteiro com a mesma finalidade.

O estabelecimento de prioridades em um texto é enfocado a seguir, recorrendo-se à organização de árvores de significado como estratégia e a elaboração de pirâmides com base no já clássico modelo de no ápice se alocar o conhecimento essencial, na base os detalhes de conhecimentos de apoio e na parte entre elas os fatos intermediários e de influência a curto prazo.

A segunda parte é a apresentação de estratégias práticas, sendo que para cada uma delas são descritos os processos cognitivos envolvidos, as estruturas textuais e as atividades a serem desenvolvidos pelos alunos. Hávendo uma orientação para o professor de como integrar esses aspectos para obter uma aprendizagem mais interativa. Seguem as descrições das várias estratégias, sempre começando com uma breve apresentação, seguindo-se os passos para seu uso, os recursos, as vantagens e referências citadas. Às vezes, pela complexidade ou diversidade de uso da técnica aparecem subtítulos nos passos para seu emprego. É o que acontece, por exemplo no uso da tempestade cerebral antes do conhecimento usado com agrupamento de rótulos ou em seqüenciação alfabética.

As estratégias apresentadas são: organizador gráfico 
de analogias; guias de antecipação; tempestade cerebral antes do conhecimento; captura de torres; contos de personagens; mapeamento de conceitos e de definições; perspectivas diferentes de leitura; discussão na Web; interrogatório elaborativo; seguindo os personagens; Modelo Frayer; imagem orientada; estrutura de mudança histórica; fluxo da memória histórica; fichas de questões; guias de leitura interativa; (Jigsaw) seleção/ apresentação de variedade de textos; (K-W-L-Mais) do conhecer/desejar para o conhecer/aprender; ligações de aprendizagens; resumos; chave de emparelhamento para aprender; mapeamento mental; revisão por pares; guia de estudo de pontos de vista; sentenças possíveis; notas de poder; situações problemáticas; diretrizes de apoio e de proposição; diagrama em pirâmide; relação perguntaresposta; questões sequenciais em profundidade; questionando o autor; RAFT (papel/audiência/formato/tópico); ler em voz alta; salve a última palavra para mim; perspectivas das relações em ciência; análise de traços semânticos; SMART (enfoque de auto-monitoramento na leitura e pensamento); impressões de história; mapeamento de histórias; notas estruturadas; estruturas equilibradas; guia de revisão vocabular; família de palavras e análise de figuras. Todas são úteis para disciplinas diversas e níveis distintos de ensino. Entretanto, carecem de pesquisas na realidade brasileira na qual possivelmente não são conhecidas nem usadas. Seria muito útil pesquisar e difundir essas estratégias no mundo educacional brasileiro de modo a realmente mudar o que ocorre nas salas de aula e assegurar aos alunos progressos cognitivos, domínio de habilidades essenciais tornando-o mais ativo e apto a interagir produtivamente com o texto, com os colegas, os professores e com a realidade.

$\mathrm{Na}$ impossibilidade de dar ao leitor uma perspectiva de cada estratégia optou-se aqui por apresentar rapidamente uma para uma consideração geral. Optou-se pela Revisão por Pares que usada na escola fundamental trabalha muito bem o desenvolvimento da criticidade na leitura e na escrita e já é uma aprendizagem ou iniciação para a formação de avaliadores ou consultores de periódicos científicos ("referees"). Os processos cognitivos trabalhados por essa estratégia são: ativar/focalizar/selecionar/organizar chegando à integração e aplicação. A análise da estrutura textual enfoca as relações: causa-efeito; conceito-definição; problemasolução; comparação-contraste; proposição-suporte; objetivo-ação-resultado. As atividades do estudante implicam em: desenvolvimento de vocabulário, tempestade cerebral de idéias, aprendizagem cooperativa, promoção de discussão, leitura interativa, encorajamento da escrita, representação gráfica e desenvolvimento de habilidades de estudo. No aspecto cognitivo destaca-se a integraçãoaplicação. $\mathrm{Na}$ análise do texto ampliam-se principalmente as habilidades de conceituar e definir e de formular proposições e dar-lhes o devido suporte. Entre as atividades estão principalmente as relativas a aprendizagem cooperativa, as relativas a participação em discussões e o desenvolvimento de habilidades de estudo.

Uma modalidade da estratégia de Revisão por Pares é a de Pausas de Três Minutos, que é detalhada no livro. Ela implica em desenvolver três modos de pensar: resumir; identificar aspectos interessantes e fazer perguntas. Entre cada fase há uma pausa em que os alunos trocam de papéis. $O$ trabalho é desenvolvido com pares de alunos (A e B). Outra modalidade da estratégia de revisão por pares implica em trabalhar a fluência verbal a partir da apresentação oral de algo importante aprendido (em texto ou aula, ou conferência) por A (60 segundos) e B funciona como platéia, em seguida invertem-se os papéis, mantendo-se o controle de tempo e B comenta o exposto por A que tem 40 segundos para retrucar, devolvendo a palavra a B (40 segundos) para dar um retorno. Na última fase cada membro tem 20 segundos para repensar e resumir o aprendido. Pode-se fazer ajustes no tempo. Outras estratégias de revisão por pares são apresentadas.

Como nessa estratégia, outras apresentam diversas modalidades havendo ainda um amplo espaço para a criatividade docente enriquecê-las, melhorá-las, pesquisá-las.

As estratégias oferecidas por Buehl são muitas e o docente sempre encontra aqui solução para resolver problemas de aprendizagem e obter um ensino mais interativo.

Recebido em 04/06/2001

Revisado em 18/06/2001

Aceito em 21/06/2001

Sobre a autora

Geraldina Porto Witter é Coordenadora do Curso de Psicologia da UMC. Docente da Pós-Graduação em Psicologia da PUC-Campinas. 